\title{
PALLADIUM COMPLEX BEARING 3,5-BIS(BENZOTRIAZOL-1-YLMETHYL)TOLUENE LIGAND CATALYZES OXIDATIVE AMINATION OF ALLYL BUTYL ETHER
}

\author{
JOHN HURTADO ${ }^{a}$, RENÉ S. ROJAS ${ }^{a}$, EDWIN G. PÉREZ ${ }^{b}$, MAURICIO VALDERRAMA** \\ ${ }^{a}$ Departamento de Química Inorgánica, Facultad de Química, Pontificia Universidad Católica de Chile, Casilla 306, Santiago-6094411, Chile. \\ ${ }^{b}$ Departamento de Química Orgánica, Facultad de Química, Pontificia Universidad Católica de Chile.
}

(Received: July 4, 2012 - Accepted: October 19, 2012)

\begin{abstract}
The reaction of 3,5-bis(bromomethyl)toluene with benzotriazole yields the bidentate ligand 3,5-bis(benzotriazol-1-ylmethyl)toluene (1). This ligand reacts with $\left[\mathrm{PdCl}_{2}(\mathrm{cod})\right]$ ( $\mathrm{cod}=1,5$-cyclooctadiene) to give the complex $\left[\mathrm{PdCl}_{2}\{3,5\right.$-bis(benzotriazol-1-ylmethyl)tolyl $\left.\}\right]$ (2). These compounds were characterized by elemental analyses, mass spectra, and FTIR and NMR $\left({ }^{1} \mathrm{H},{ }^{13} \mathrm{C}\right)$ spectroscopies. The palladium(II) complex $\mathbf{2}$ shows high activity as catalyst for oxidative amination, involving allyl butyl ether and phthalimide as substrates and $\mathrm{PhICl}_{2}$ as a stoichiometric oxidant.
\end{abstract}

Keywords: Palladium complex; Bidentate nitrogen ligand; Aminopalladation, Oxidative amination

\section{INTRODUCTION}

The syntheses of late transition metal complexes have received much attention due to their potential applications for olefin polymerization catalysis. ${ }^{1,2}$ The discovery of a new class of catalysts based on Ni(II) or Pd(II) $\alpha$-diimine compounds by Brookhart et al. ${ }^{3}$, has been followed by a considerable development of related bidentate nitrogen donor ligands. ${ }^{4-8}$ Another family of active late transition metal polymerization catalysts based on pyrazol and poly(pyrazolyl) ligands has been described. ${ }^{9-16}$ These types of ligands are attractive since their steric and electronic properties can be changed by the appropriate selection of the substituents in the pyrazol ring.

In the last few years we have been interested in the synthesis of early and late transition metal complexes containing pyrazolyl derivatives as ligands, which can polymerize ethylene under mild conditions. ${ }^{17-22}$ Recently, we described the synthesis of new palladium complexes bearing the bidentate 3,5-bis(azol-1ylmethyl)toluene ligands ( $\mathrm{azol}=3,5$-dimethylpyrazol, indazol), which in the presence of methylaluminoxane lead to active catalysts for the polymerization of ethylene. ${ }^{23}$ The palladium(II) complex containing 3,5-bis(indazol-1ylmethyl)toluene is active as catalysts in C-C coupling reactions involving aryl halides substrates. ${ }^{24}$

On the other hand, a variety of palladium(II) complexes have been successfully studied as catalysts for the aerobic oxidative amination of unactivated alkenes to yield amine derivatives. ${ }^{25-38}$ This catalytic reaction leads to the formation of imines or enamines, via $\beta$-hydride elimination, through a mechanism analogous to the well-known Wacker process. ${ }^{25}$

In this communication we report the synthesis and characterization of the new ligand 3,5-bis(benzotriazol-1-ylmethyl)toluene (1) and its palladium(II) complex of formula $\left[\mathrm{PdCl}_{2}\{3,5\right.$-bis(benzotriazol-1-ylmethyl)tolyl $\left.\}\right]$ (2). Complex 2 and $\left[\mathrm{PdCl}_{2}\{3,5\right.$-bis(3,5-dimethylpyrazol-1-ylmethyl)toluene $\left.\}\right]$ (3), previously reported ${ }^{23}$, are active catalysts for oxidative amination of allyl butyl ether under mild conditions, employing $\mathrm{PhICl}_{2}$ as a stoichiometric oxidant.

\section{EXPERIMENTAL}

2.1. General

All manipulations were performed in an inert atmosphere (nitrogen) using standard glove box and Schlenk techniques. All materials were purchased from Aldrich and used as received. The complexes $\left[\mathrm{PdCl}_{2}\{3,5-\right.$ bis(3,5-dimethylpyrazol-1-ylmethyl)toluene $\}]$ (3) and $\left[\mathrm{PdCl}_{2}(\operatorname{cod})\right](\operatorname{cod}=1$, 5 -cyclooctadiene) were prepared according to published methods. ${ }^{23,39}$ NMR spectra were recorded on a Bruker Avance-400 spectrometer. FTIR spectra were recorded on a Bruker Vector-22 spectrophotometer using $\mathrm{KBr}$ discs. Elemental analyses $(\mathrm{C}, \mathrm{H}, \mathrm{N})$ were performed on a Fisons EA $1108 \mathrm{CHNS}-\mathrm{O}$ microanalyzer. Mass spectra were obtained on a Micromass Quattro LC-Z electrospray mass spectrometer.

2.2. Synthesis of 3,5-bis(benzotriazol-1-ylmethyl)toluene (1)

In a Schlenk flask equipped with a reflux condenser, benzotriazole (715 $\mathrm{mg}$; $6.0 \mathrm{mmol}$ ), 3,5-bis(bromomethyl)toluene ( $834 \mathrm{mg} ; 3.0 \mathrm{mmol}$ ) and toluene $(30 \mathrm{~mL})$ were added and the mixture heated under reflux for $48 \mathrm{~h}$. The resulting mixture was filtered and the toluene solution cooled to yield a white solid. The solid residue was purified by crystallization from chloroform-diethyl ether. Yield $570 \mathrm{mg}(54 \%)$. M.p.: $142-143{ }^{\circ} \mathrm{C}$. ME-ESI $\left(\mathrm{m} / \mathrm{z}, \mathrm{ES}^{+}\right): 354.16[\mathrm{M}]^{+}$, $377.14[\mathrm{M}+\mathrm{Na}]^{+}$. Anal. Calcd. for $\mathrm{C}_{2} \mathrm{H}_{1} \mathrm{~N}: \mathrm{C}, 71.17 ; \mathrm{N}, 23.71 ; \mathrm{H}, 5.12 \%$. Found: C, 71.03; N, 23.34; H, $5.21 \%$. FTIR $\left(\mathrm{KBr}, \mathrm{cm}^{-1}\right): v 1614 \mathrm{~m}, 1496 \mathrm{~m}$, $1454 \mathrm{~s}, 1221 \mathrm{~s}, 1158 \mathrm{~m}, 1093 \mathrm{~s}, 781 \mathrm{~s}, 745 \mathrm{~s}$. Atom numbering for compound (1) is as follows:<smiles>Cc1cc(Cn2nnc3ccccc32)cc(Cn2nnc3ccccc32)c1</smiles>

NMR (DMSO-d, $295 \mathrm{~K}):{ }^{1} \mathrm{H}, \delta 2.2\left(\mathrm{~s}, 3 \mathrm{H}, \mathrm{CH}_{3}\right), 5.7\left(\mathrm{~s}, 4 \mathrm{H}, \mathrm{CH}_{2}\right), 6.9(\mathrm{~s}$, $\left.2 \mathrm{H}, 2,2^{\prime}\right), 7.0(\mathrm{~s}, 1 \mathrm{H}, 4), 7.2\left(\mathrm{t}, \mathrm{J}=8.0 \mathrm{~Hz}, 2 \mathrm{H}, 8,8^{\prime}\right), 7.3\left(\mathrm{t}, \mathrm{J}=8.0 \mathrm{~Hz}, 2 \mathrm{H}, 9,9^{\prime}\right)$ $7.6\left(\mathrm{~d}, \mathrm{~J}=8.4 \mathrm{~Hz}, 2 \mathrm{H}, 7,7^{\prime}\right)$ and $7.9\left(\mathrm{~d}, \mathrm{~J}=8.0 \mathrm{~Hz}, 2 \mathrm{H}, 10,10^{\prime}\right) \mathrm{ppm} .{ }^{13} \mathrm{C}\left\{{ }^{1} \mathrm{H}\right\}$, $\delta 21\left(\mathrm{CH}_{3}\right), 52\left(\mathrm{CH}_{2}\right), 110\left(\mathrm{C}^{2}, \mathrm{C}^{\prime}\right), 119\left(\mathrm{C} 10,10^{\prime}\right), 124(\mathrm{C} 4), 124\left(\mathrm{C} 8,8^{\prime}\right)$, 127 (C9, 9'), $128\left(\mathrm{C}^{\prime}, 2^{\prime}\right), 132$ (C3, 3'), 136 (C6, 6'), 140 (C1) and 145 (C11, 11') $\mathrm{ppm}$.

2.3. Synthesis of $\left[\mathrm{PdCl}_{2}\{3,5\right.$-bis(benzotriazol-1-ylmethyl)tolyl $\left.\}\right]$ (2)

In a Schlenk flask equipped with a reflux condenser, $\left[\mathrm{PdCl}_{2}(\mathrm{cod})\right]$ (1,5-ciclooctadiene) (57 mg; $0.2 \mathrm{mmol}), 3,5$-bis(benzotriazol-1-ylmethyl) toluene $(71 \mathrm{mg}, 0.2 \mathrm{mmol})$ and acetonitrile $(15 \mathrm{~mL})$ were added and the mixture heated under reflux for $2 \mathrm{~h}$. The yellow solid formed was filtered off, washed with acetonitrile and diethyl ether, and dried under vacuum. This complex was insoluble in standard NMR solvents. Yield $88 \mathrm{mg}(83 \%)$. FTIR $\left(\mathrm{KBr}, \mathrm{cm}^{-1}\right): v 1664 \mathrm{~m}, 1599 \mathrm{~s}, 1318 \mathrm{~m}, 1238 \mathrm{~m}, 1171 \mathrm{~m}, 746 \mathrm{~s}, 350 \mathrm{w}$. Anal. Calcd for $\mathrm{C}_{21} \mathrm{H}_{18} \mathrm{~N}_{6} \mathrm{PdCl}_{2}: \mathrm{C}, 47.43 ; \mathrm{N}, 15.81 ; \mathrm{H}, 3.41 \%$. Found: $\mathrm{C}, 47.37 ; \mathrm{N}, 15.63$; $\mathrm{H}, 3.50 \%$.

\subsection{Oxidative amination reaction}

General procedure for the reaction screening condition: In a glass test tube, allyl butyl ether $(30 \mathrm{mg} ; 0.6 \mathrm{mmol})$, phthalimide $(91 \mathrm{mg} ; 0.8 \mathrm{mmol})$, catalyst $(0.02 \mathrm{mmol})$, oxidant $(0.4 \mathrm{mmol})$ and solvent $(12.5 \mathrm{~mL})$ were added. The resulting mixture was stirred at $70^{\circ} \mathrm{C}$ for $16 \mathrm{~h}$. The obtained solution was reduced, and 1,3,5-trimethoxybenzene $(1 \mathrm{~mL}$ of a known concentration solution in $\mathrm{CDCl}_{3}$ ) was added. The oxidative amination product (3-butoxy2-phthalimide)propene was evaluated by ${ }^{1} \mathrm{H}-\mathrm{NMR}$ spectroscopy relative to the internal standard. For the isolated yield, the solvent was removed and the product purified by silica gel column chromatography (type 60), using 
dichloromethane as eluent to give a white oil, air stable at room temperature. ME-ESI (m/z, ES $\left.{ }^{+}\right): 259.30[\mathrm{M}]^{+}, 282.289[\mathrm{M}+\mathrm{Na}]^{+}$. FTIR $\left(\mathrm{KBr}, \mathrm{cm}^{-1}\right): v 1721 \mathrm{~s}$ $(\mathrm{C}=\mathrm{O}), 1378 \mathrm{~m}, 1108 \mathrm{w}, 717 \mathrm{w}$. Atom numbering for compound is as follows:

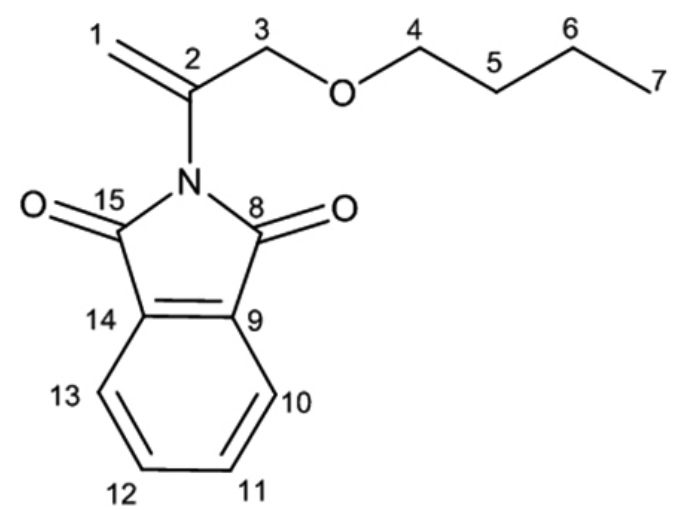

$\operatorname{NMR}\left(\mathrm{CDCl}_{3}, 295 \mathrm{~K}\right):{ }^{1} \mathrm{H}, \delta 0.81(\mathrm{t}, \mathrm{J}=7.5 \mathrm{~Hz}, 3 \mathrm{H}, 7), 1.24(\mathrm{~m}, 2 \mathrm{H}, 6)$, $1.51(\mathrm{~m}, 2 \mathrm{H}, 5), 3.43(\mathrm{t}, \mathrm{J}=6.42 \mathrm{H}, 4), 4.28(\mathrm{~s}, 2 \mathrm{H}, 3), 5.37(\mathrm{~s}, 1 \mathrm{H}, 1), 5.62(\mathrm{~s}$, $1 \mathrm{H}, 1), 7.73(\mathrm{~m}, 2 \mathrm{H}, 11,12)$ and $7.88(\mathrm{~m}, 2 \mathrm{H}, 10,13) \mathrm{ppm} .{ }^{13} \mathrm{C}\left\{{ }^{1} \mathrm{H}\right\}, \delta 14(\mathrm{C} 7)$, 19 (C6), 32 (C5), 69 (C4), 70 (C3), 116 (C1), 124 (C11, C12), 132 (C2), 134 $(\mathrm{C} 10, \mathrm{C} 13), 136$ (C9, C14), $167(\mathrm{C} 15)$ and $169(\mathrm{C} 8) \mathrm{ppm}$.

\section{RESULTS AND DISCUSSION}

The compound 3,5-bis(benzotriazol-1-ylmethyl)toluene (1) was synthesized by reaction of 3,5-bis(bromomethyl)toluene with two equivalents of benzotriazole in refluxing toluene. The compound was isolated as a white solid, air stable at room temperature, soluble in acetone, dichloromethane and chloroform, and was characterized by elemental analysis, mass spectra, and FTIR and NMR $\left({ }^{1} \mathrm{H},{ }^{13} \mathrm{C}\right)$ spectroscopies. The ${ }^{1} \mathrm{H}$ and ${ }^{13} \mathrm{C}$ NMR spectra are consistent with the formation of a single isomer. Its formulation was established on the basis of ${ }^{1} \mathrm{H}$ and ${ }^{13} \mathrm{C}$ NMR data and elemental analysis. The ${ }^{1} \mathrm{H}$ and ${ }^{13} \mathrm{C}$ chemical shifts were assigned with the aid of ${ }^{1} \mathrm{H}^{-1} \mathrm{H}^{1}$ (COSY), DEPT, ${ }^{1} \mathrm{H}^{-13} \mathrm{C}$ (HMQC), HMBC and NOESY experiments. Diagnostic peaks include (in ppm): $\delta 2.26\left(\mathrm{~s}, 3 \mathrm{H}_{1} \mathrm{CH}_{3}\right), 5.7\left(\mathrm{~s}, 4 \mathrm{H}, \mathrm{CH}_{2}\right)$ and $7.9(\mathrm{~d}, 2 \mathrm{H}, \mathrm{H10}, 10$ '-triazolyl).

As shown in Scheme 1, the triazolyl groups are connected to the methylene spacers through the N1 atom.

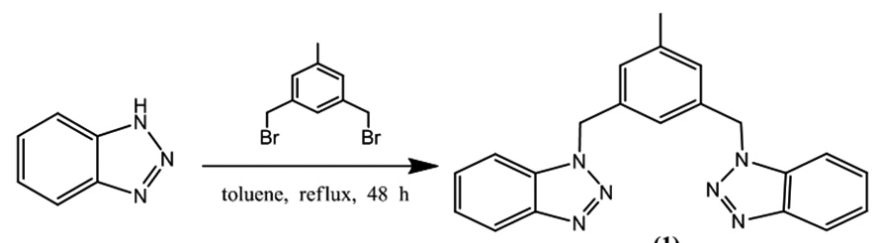

(1)

Scheme 1. Synthesis of 3,5-bis(benzotriazol-1-ylmethyl)toluene (1)

The reaction of 1 with $\left[\mathrm{PdCl}_{2}(\operatorname{cod})\right]$ in refluxing acetonitrile gives a compound of general formula $\left[\mathrm{PdCl}_{2}\{3,5\right.$-bis(benzotriazol-1-ylmethyl) toluene\}] (2). Complex 2 was isolated as a yellow solid, air stable at room temperature. Due to the insoluble nature of complex 2 in standard NMR solvents the proposed stoichiometry is mainly supported by elemental analysis and FT-IR spectra. Although mononuclear or binuclear complexes have been obtained using related bis(azolyl) ligands, ${ }^{12,13,22}$ in our case the isolation of non-soluble material indicates the probable formation of a polymeric species with the ligand acting as N,N-bridge between two palladium centers. This assumption is supported by the presence of one band at $350 \mathrm{~cm}^{-1}$ in the infrared spectrum, assigned to the stretching frequency of the Pd-Cl bond, which is characteristic of a trans dichloride isomer. ${ }^{40}$

Considering that a variety of palladium(II) complexes have been successfully studied as catalysts in oxidative amination of alkenes reactions, ${ }^{25-37}$ we tested the behavior of complexes $\mathbf{2}$ and $\mathbf{3}$ in the reaction of phthalimide with allyl butyl ether.

The catalytic behavior in the presence of two different oxidants and solvents are summarized in Table 1.

Table 1. Oxidative amination of allyl butyl ether. ${ }^{\mathrm{a}}$

\begin{tabular}{|c|c|c|c|c|}
\hline Entry & [Pd] $10 \%$ & {$[\mathrm{O}]$} & Solvent $1.0 \mathrm{~mL}$ & Yield $(\%)^{\mathrm{b}}$ \\
\hline 1 & 2 & $\mathrm{PhI}(\mathrm{OAc})_{2}$ & EtOAc & $43^{\mathrm{c}}$ \\
\hline 2 & 2 & $\mathrm{PhI}(\mathrm{OAc})_{2}$ & DCE & $67^{\mathrm{c}}$ \\
\hline 3 & 2 & $\mathrm{PhI}(\mathrm{OAc})_{2}$ & THF & $55^{\mathrm{c}}$ \\
\hline 4 & 2 & $\mathrm{PhI}(\mathrm{OAc})_{2}$ & Toluene & NR \\
\hline 5 & 2 & $\mathrm{PhI}(\mathrm{OAc})_{2}$ & DMF & NR \\
\hline 6 & 2 & $\mathrm{PhI}(\mathrm{OAc})_{2}$ & $\mathrm{CHCl}_{3}$ & NR \\
\hline 7 & 2 & $\mathrm{PhI}(\mathrm{OAc})_{2}$ & Dioxane & $22^{c}$ \\
\hline 8 & 2 & $\mathrm{PhI}(\mathrm{OAc})_{2}$ & $\mathrm{CH}_{3} \mathrm{CN}$ & 34 \\
\hline 9 & 2 & $\mathrm{PhI}(\mathrm{OAc})_{2}$ & Benzene & NR \\
\hline 10 & 2 & $\mathrm{PhICl}_{2}$ & DCE & 86 \\
\hline 11 & 2 & $\mathrm{PhICl}_{2}$ & DCE & $80^{\mathrm{d}}$ \\
\hline 12 & 3 & $\mathrm{PhICl}_{2}$ & DCE & 80 \\
\hline 13 & 3 & $\mathrm{PhICl}_{2}$ & DCE & $75^{d}$ \\
\hline 14 & $\mathrm{Pd}(\mathrm{OAc})_{2}$ & $\mathrm{PhI}(\mathrm{OAc})_{2}$ & DCE & 66 \\
\hline 15 & - & $\mathrm{PhICl}_{2}$ & DCE & 0 \\
\hline
\end{tabular}

a PhtNH: Phthalimide $(0.2 \mathrm{mmol} ; 30 \mathrm{mg})$, AbE: Allyl butyl ether $(0.8 \mathrm{mmol}$; $91 \mathrm{mg}$ ), [O] $0.4 \mathrm{mmol}$, at $70^{\circ} \mathrm{C}$ for $16 \mathrm{~h} .{ }^{\text {b }}{ }^{\mathrm{H}} \mathrm{H}$ NR yield relative to phthalimide as the limiting reagent (Internal standard $=1,3,5$-trimethoxybenzene). Black palladium was observed. ${ }^{\mathrm{d}}$ Isolated yield after purification by column chromatography.

Analysis of the data showed that the best solvent is 1,2-dichloroethane (DCE, entries 2,10-14). When $\mathrm{PhI}(\mathrm{OAc})_{2}$ is used (entry 2) there is partial decomposition with formation of palladium metal. $\mathrm{PhICl}_{2}$, however was found to be a suitable oxidant ${ }^{41,42}$. The new complex $\mathbf{2}$ has slightly higher yields than complex 3 under similar conditions (entries 10-13), probably due to the fact that the more extended conjugation of the benzotriazole rings makes the metal center more electron deficient and consequently increases the reactivity. The use of $\mathrm{Pd}(\mathrm{OAc})_{2}$ as catalyst has the lowest yield (entry 14); this result is likely to be due to the difficulty in stabilizing the active species (Scheme 2).

Although with our data no detailed reaction mechanism can be proposed, a plausible path is shown in Scheme 2. The reaction is thought to proceed by the Markownikov aminopalladation of the olefin to produce the intermediate A with loss of $\mathrm{HCl}$. The intermediate $\mathbf{A}$ is likely to undergo $\beta$-hydride elimination, resulting in the functionalization of the olefin at the $\mathrm{C} 2$ position to give the enimide compound $\mathbf{Y}$, and the intermediate $\mathbf{B},\left[\mathrm{Pd}^{\mathrm{II}}\right] \mathrm{CHCl}$, which subsequently through a reductive elimination reaction loses another $\mathrm{HCl}$ molecule yielding $\mathbf{C},\left[\mathrm{Pd}^{0}\right]$. Oxidation of the resulting $\left[\mathrm{Pd}^{0}\right]$ intermediate with $\mathrm{PhICl}_{2}$ could then form the initial catalyst and iodobenzene. Studies of similar complexes in oxidative amination reactions are currently under investigation in our laboratory. 


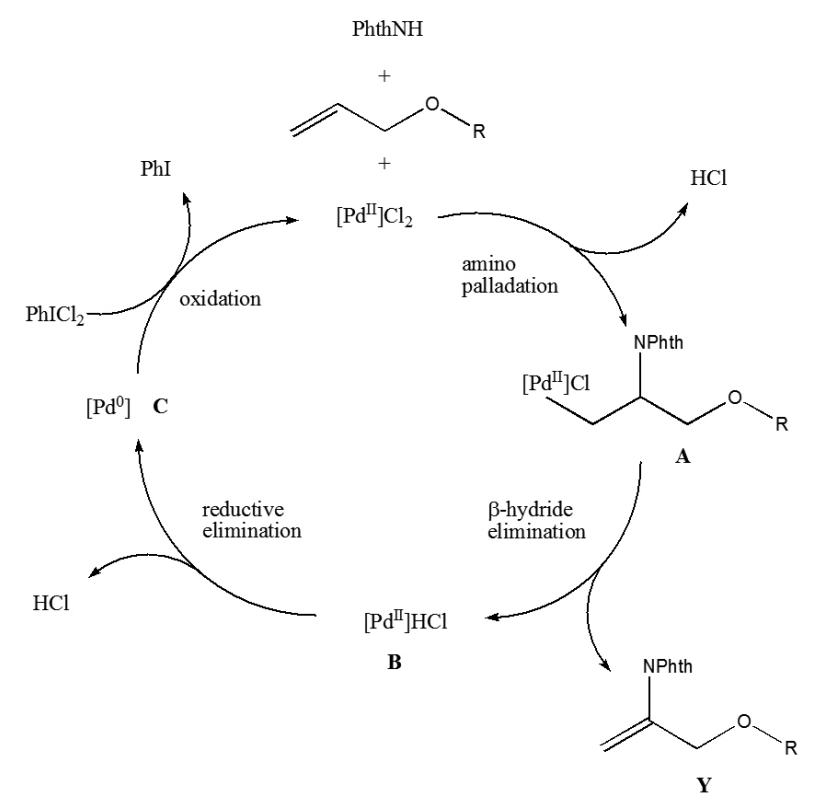

Scheme 2. A plausible pathway of the oxidative amination

\section{CONCLUSIONS}

In summary, we have synthesized and characterized the new ligand 3,5-bis(benzotriazol-1-ylmethyl)toluene (1) and the compound $\left[\mathrm{PdCl}_{2}\{3,5-\right.$ bis(benzotriazol-1-ylmethyl)tolyl\}] (2) in good yields. The palladium complexes $(2,3)$ show high activity as catalyst for oxidative amination, involving allyl butyl ether and phthalimide as substrates, using $\mathrm{PhICl}_{2}$ as a stoichiometric oxidant under mild conditions.

\section{ACKNOWLEDGEMENTS}

We thank $\square$ Fondo de Desarrollo Científico y Tecnológico $\square$ (FONDECYT), Chile, for financial support under projects $\mathrm{N}^{\circ} 1060597$ and 1100286. J.H. acknowledges VRI, Pontificia Universidad Católica de Chile and CONICYT for a doctoral fellowship.

\section{REFERENCES}

1. S. D. Ittel, L. K. Johnson, M. Brookhart, Chem. Rev. 100, 1169, (2000).

2. V. C. Gibson, S. K. Spitzmesser, Chem. Rev. 103, 283, (2003).

3. L. K. Johnson, C. M. Killian, M. Brookhart, J. Am. Chem. Soc. 117, 6414, (1995).

4. D. Pappalardo, M. Mazzeo, C. Pellecchia, Makromol. Rapid Commun. 18, 1017, (1997).

5. T. Schleis, J. Heinemann, T. P. Spaniol, R. Mülhaupt, J. Okuda, Inorg. Chem. Commun. 1, 43, (1998).

6. T. Schleis, T. P. Spaniol, J. Okuda, J. Heinemann, R. Mülhaupt, J. Organomet. Chem. 569, 159, (1998).

7. J. Yi, X. Huang, W. Zhang, X. Hong, Z. Jing, J. Gas. Nat. Chem. 12, 98 (2003).

8. Z. Huang, H. Gao, L. Zhang, Q. Wu, Chinese Journal of Catalysis 26, 567, (2008).

9. S. Tsuji, D. C. Swenson, R. F. Jordan, Organometallics 18, 4758, (1999).

10. K. Li, J. Darkwa, I. A. Guzei, S. F. Mapolie, J. Organomet. Chem. 660, 108, (2002).

11. S. M. Nelana, J. Darkwa, I. A. Guzei, S. F. Mapolie, J. Organomet. Chem. 689, 1835 (2004).

12. I. A. Guzei, K. Li, G. A. Bikzhanova, J. Darkwa, S. F. Mapolie, Dalton Trans. 715, (2003).

13. K. Li, M. S. Mohlala, T. V. Segapelo, P. S. Shumbula, I. A. Guzei, J. Darkwa, Polyhedron 27, 1017, (2008).

14. M. Mohlala, I. A. Guzei, J. Darkwa, S. F. Mapolie, J. Mol. Catal. A: Chem. 241, 93, (2005).

15. N. Ajellal, M. C. A. Kuhn, A. D. G. Boff, M. Hörner, C. M. Thomas, J. F. Carpentier, O. L. Casagrande, Organometallics 25, 1213, (2006).
16. S. O. Ojwach, I. A. Guzei, L. L. Benade, S. F. Mapolie, J. Darkwa, Organometallics 28, 2127, (2009).

17. R. Rojas, M. Valderrama, G. Wu, Inorg. Chem. Commun. 7, 1295, (2004).

18. I. García-Orozco, R. Quijada, K. Vera, M. Valderrama, J. Mol. Catal. A: Chem. 260, 70, (2006).

19. J. Hurtado, D. McLeod-Carey, A. Muñoz-Castro, R. Arratia-Pérez, R. Quijada, G. Wu, R. Rojas, M. Valderrama, J. Organomet. Chem. 694, 2636, (2009).

20. J. Hurtado, A. Ibañez, R. Rojas, M. Valderrama, R. Fröhlich, J. Braz. Chem. Soc. 22, 1750, (2011).

21. R. Caris, B. C. Peoples, M. Valderrama, G. Wu, R. Rojas, J. Organomet. Chem. 694, 1795, (2009).

22. J. Hurtado, J. Ugarte, R. Rojas, M. Valderrama, D. MacLeod-Carey, A. Muñoz-Castro, R. Arratia-Pérez, R. Fröhlich, Inorg. Chim. Acta 378, 218 , (2011).

23. J. Hurtado, M. Portaluppi, R. Quijada, R. Rojas, M. Valderrama, J. Coord. Chem. 62, 2772, (2009).

24. J. Hurtado, A. Ibañez, R. Rojas, M. Valderrama, Inorg. Chem. Commun. 13,1025, (2010).

25. T. E. Müller, M. Beller, Chem. Rev. 98, 675, (1998).

26. S. Hong, T. J. Marks, Acc. Chem. Res. 37, 673, (2004).

27. M. Becalli, G. Broggini, M. Martinelli, S. Sottocornola, Chem. Rev. 107, 5318, (2007).

28. S. S. Stahl, Angew. Chem. Int. Ed. 43, 3400, (2004).

29. Y. Obora, Y. Shimizu, Y. Ishii, Org. Lett. 11, 5058, (2009).

30. G. Liu, G. Y. Yin, L. Wu, Angew. Chem. Int. Ed. 47, 4733, (2008) and references therein

31. K. J. Fraunhoffer, M. C. White, J. Am. Chem. Soc. 129, 7274, (2007).

32. M. M. Rogers, J. E. Wendlandt, I. A. Guzei, S. S. Stahl, Org. Lett. 8, 2257, (2006).

33. J. L. Brice, J. E. Harang, V. I. Timokhin, N. R. Anastasi, S. S. Stahl, J. Am. Chem. Soc. 127, 2868, (2005).

34. S. S. Stahl, Science 309, 1824, (2005).

35. V. I. Timokhin, S. S. Stahl, J. Am. Chem. Soc. 127, 17888, (2005).

36. V. I. Timokhin, N. R. Anastasi, S. S. Stahl, J. Am. Chem. Soc. 125, 12996, (2003).

37. P. Diversi, L. Ermini, G. Ingrosso, A. Lucherini, C. Pinzino, L. Sagramora, J. Organomet. Chem. 494, C1, (1995).

38. R. L. Cowan, W. C. Trogler, J. Am. Chem. Soc. 111, 4750, (1989).

39. D. Drew, J. R. Doyle, A. G. Shaver, Inorg. Synth. 13, 47, (1972).

40. K. Nakamoto.'Infrared Spectra of Inorganic and Coordination Compounds". $2^{\text {nd }}$ Edition, Wiley-Interscience. New York, 1970.

41. L. W. Desai, M. S. Sanford, Angew. Chem. Int. Ed. 46, 5737, (2007)

42. D. Kalyani, M. S. Sanford, J. Am. Chem. Soc. 130, 2150, (2008). 